\title{
Lipase Maturation Factor 1
}

National Cancer Institute

\section{Source}

National Cancer Institute. Lipase Maturation Factor 1. NCI Thesaurus. Code C134608.

Lipase maturation factor 1 (567 aa, $\sim 65 \mathrm{kDa}$ ) is encoded by the human LMF1 gene. This protein plays a role in the maturation of lipoprotein lipase. 